\title{
Клинический случай лечения пациента с дорсопатией шейного отдела позвоночника с применением биорегуляционных препаратов
}

\section{Реферат (абстракт)}

В представленном клиническом случае у пациента с дорсопатией шейного отдела позвоночника с спондилогенной цервикалгией мышечно-тонического характера описаны результаты применения биорегуляционных препаратов компании Heel.

\section{Ключевые слова:}

Дорсопатия шейного отдела позвоночника, спондилогенная цервикалгия, Траумель С, биорегуляционные препараты

\begin{abstract}
Введение
Дегенеративно-дистрофические заболевания опорно-двигательного аппарата-наиболее частая проблема, приводящая к снижению качества жизни пациента. Это связано с особенностями течения заболевания, высокой частотой обострений, неудовлетворительными результатами терапии, переходом болевого синдрома в хроническую форму и приводящее к инвалидности.
\end{abstract}

\section{Описание случая}

Пациент: N женщина 42 лет

Жалобы на боли и скованность в шейном отделе позвоночника с частыми обострениями. В настоящее время обострение. боли 7-8 баллов по ВАШ. Боли в ночное время. обследована ревматологом. Системного ревматологического заболевания не выявлено. Дополнительно жалуется на постоянную заложенность носа и нарушение носового дыхания. Заключение лора после осмотра: вазомоторный ринит.

\section{Диагноз}

Дорсопатия шейного отдела позвоночника. Спондилогенная цервикалгия мышечно-тоническая подострая.

(код МКБ-10)

Ј30.0 Вазомоторный ринит 


\section{Анамнез жизни}

Родилась доношенной, в срок. Перенесла ветрянку, корь в 2 и 5 лет соответственно, без осложнений. Менструальный цикл с 12 лет регулярный. 1 беременность, 1 роды. Ребенок/мальчик 12 лет здоров. Гепатит, венерические заболевания отрицает. АД стабильное. Постоянно лекарственных препаратов не принимает. За пределы РФ не выезжала в течение полугода. Привита от новой короновирусной инфекции вакциной Спутник V. Вакцинация без осложнений. Аллергологический анамнез: зуд при приеме НПВП

\section{Анамнез заболевания}

Боли в шее около 10 лет. Впервые появились после охлаждения. Уменьшаются после использования НПВС и миорелаксантов. Однако эффект данных групп препаратов снижается. Отмечает побочные эффректы от проводимой ранее терапии в виде кожного зуда и нарушения стула.

\section{Клиническая картина}

Общее состояние удовлетворительное. Эмоциональная лабильность. Кожные покровы и видимые слизистые чистые. АД 122/77, пульс 68 в минуту, ритмичный. Носовое дыхание нарушено. Болезненна пальпация точек выхода 2 ветви тройничных нервов с двух сторон. Черепно-мозговые нервы без патологии. Сухожильные рефлексы симметричные, умеренные. Парезов нет. Атрофиий нет. Все виды чувствительности сохранны. Болезненность и напряжение шейных мышц, дефанс до 2 степени. Симптом Нери ++ Болезненность при пальпации в точках Эрба. Ограничены латерофлексии в шейном отделе позвоночника.

\section{Методы диагностики}

По данным рентгена шейного отдела позвоночника - шейный лордоз сглажен, снижена высота дисков С3-4; C4-5. Клинический анализ крови в норме. ЭКГ вариант нормы.

\section{Лекарственная терапия}

Траумель® С 2,2 мл внутримышечно через день 10 инъекций.

Лимфомиозот 2,2 мл внутримышечно через день, чередовать с Траумель ®С. Нейроуридин 1 капсула в сутки за завтраком 20 дней.

Воротник Шанса носить по 30 минут 4 раза в течение дня.

\section{Коррекция схемы лечения пациента}

Для продолжения лечения назначена пероральная форма Траумель ®С по 1 таблетку рассасывать 4 раза в день.

Нервохель 1 табалетка 2 раза в день. Местно: Траумель $® C$ мазь 2 раза в день в течение 2 недель.

Местно спрей Эуфрорбиум композитум по 1 впрыска 4 раза в день 15 дней.

\section{Результаты лечения}


через 26 дней после первого визита, на Зм приеме пальпация шейного отдела безболезненна, объем движений в шейном отделе достаточный. Отмечает значительное улучшение носового дыхания. Купирование болевого синдрома. Нормализация мышечного тонуса и объема движений в шейном отделе позвоночника.

\section{Выводы и обсуждения}

В данном клиническом случае использование биорегуляционных препаратов для лечения частых обострений дорсопатии дает стойкий клинический эффрект. Учитывая аллергическую реакцию у пациентки на НПВС, данный вариант лечения является оптимальным и безопасным.

Многофакторный профиль биорегуляционных препаратов способствовал восстановлению носового дыхания и значительному уменьшению проявлений вазомоторного ринита.

Список литературы:

1. Лечение больных с неврологическими проявлениями остеохондроза позвоночника Методические рекомендации. Воронежская государственная медицинская академия им. Н. Н. Бурденко изд. Медпрактика Москва 2005 г.

2. Дисциркуляция в вертебробазилярной системе при патологии шейного отдела позвоночника [Текст]: (Вопросы диагностики) / В.М. Салазкина, Л.К. Брагина, И.Я. Калиновская.Москва : Медицина, 2010.

3. Дыдыкина И.С., Зоткин Е.Г., Коваленко П. С. Вклад биорегуляционной терапии в лечение заболеваний костно-мышечной системы. Резолюция по результатам форума 01.03.2019. Consilium Medicum. 2019; 21 (9): 103-109. DOI: 10.26442/20751753.2019.9.190612 